\title{
Risk behavior for the Human Immunodeficiency Virus among motel clients
}

\author{
Helisamara Mota Guedes ${ }^{1}$ \\ Luciana Oliveira Costa Cabral ${ }^{2}$ \\ Maria Verônica de Barros Costa² \\ Alex Ferreira dos Reis ${ }^{3}$ \\ Simone Gomes Pereira² \\ Fernanda Oliveira-Ferreira ${ }^{4}$
}

This study aimed to verify risk behavior for infection with the Human Immunodeficiency Virus in people who attended motels. This is a cross-sectional study conducted in two motels in two municipalities in the state of Minas Gerais, Brazil, with a sample of 308 randomly selected individuals, aged between 18 and 60 years. Bivariate (chi-square and test for independent samples) and multivariate (logistic regression) statistical tests were performed. A total of $45.8 \%$ of the participants reported not having used a condom during the last vaginal sexual intercourse, $48.4 \%$ did not use a condom during the last oral sex, while $26.3 \%$ reported not having used a condom in the last anal intercourse. Having a steady partner was the strongest predictor of not using condoms. Probable beliefs regarding loyalty involved in a stable relationship may be contributing to the failure to use condoms during intercourse, increasing the risk of HIV infection.

Descriptors: HIV; Sexual Behavior; Condoms; Sexuality.

\footnotetext{
${ }^{1}$ Doctoral Student, Universidade Federal de Minas Gerais, Brazil. Assistant Professor, Departamento de Enfermagem, Universidade Federal dos Vales do Jequitinhonha e Mucuri, Brazil.

${ }^{2}$ Undergraduate students in Nursing, Centro Universitário do Leste de Minas Gerais, Brazil.

${ }^{3}$ Undergraduate student in Nursing, Centro Universitário do Leste de Minas Gerais, Brazil. Scholarship holder from Programa de Iniciação Científica PIC Unileste.

${ }^{4}$ PhD, Adjunct Professor, Departamento de Ciências Básicas, Universidade Federal dos Vales do Jequitinhonha e Mucuri, Brazil.
} 


\section{Comportamentos de risco frente ao vírus da imunodeficiência humana entre frequentadores de motéis}

Este estudo teve por objetivo verificar comportamentos de risco referentes à infecção pelo vírus da imunodeficiência humana (HIV) em pessoas que frequentaram motéis. Trata-se de estudo transversal, realizado em dois motéis de dois municípios do interior de Minas Gerais, com amostra de 308 indivíduos, seguindo cálculo amostral, selecionados aleatoriamente, com idade entre 18 e 60 anos. Foram realizados testes estatísticos bivariados (qui-quadrado e teste $\mathrm{t}$ para amostras independentes) e multivariados (regressão logística). Dentre os participantes, $45,8 \%$ relataram não ter usado preservativo na última relação sexual vaginal, $48,4 \%$ não utilizaram preservativo na última relação sexual oral, enquanto $26,3 \%$ afirmaram não ter usado na última relação anal. Ter um parceiro fixo foi o maior preditor do não uso do preservativo. Prováveis crenças de fidelidade, envolvidas em um relacionamento estável, podem estar contribuindo para o não uso do preservativo nas relações, aumentando o risco de infecção pelo HIV.

Descritores: HIV; Comportamento Sexual; Preservativos; Sexualidade.

\section{Las conductas de riesgo al virus de inmunodeficiencia humana entre usuarios de moteles}

Este estudio tuvo como objetivo determinar las conductas de riesgo al virus de inmunodeficiencia humana en personas que asistieron moteles. Estudio transversal realizado en dos moteles en dos municipios de Minas Gerais con una muestra de 308 personas. Bivariado se realizaron pruebas estadísticas (Jue-cuadrado y $\mathrm{t}$ para muestras independientes) y multivariado (regresión logística). La mayoría (42,5\%) tenían entre 18 y 25 años y el $45,8 \%$ no había utilizado preservativo en sus últimas relaciones sexuales vaginales, $48,4 \%$ no usó condón para sexo oral, mientras que 26,3 \% reportó no haber utilizado el su última relación anal. Tener una pareja estable fue el mejor predictor para no usarse condones. Llegamos a la conclusión de que la lealtad tiende a estar involucrada en una relación estable puede estar contribuyendo a la no utilización de preservativos en las relaciones, aumentando la vulnerabilidad.

Descriptores: VIH; Conducta sexual; Condones; Sexualidad.

\section{Introduction}

The concerns emerging in the early 1990's due to the large number of people infected with the human immunodeficiency virus (HIV) raised questions for society regarding sexual practices, with the intention of better comprehending the relationship between these practices and HIV infection. In Brazil, the epidemiological profile of HIV and of the acquired immunodeficiency syndrome (AIDS) present important regional differences and diverse effects in society, with variations regarding gender, race, social class and intellectual level(1). From 1980 to June 2011, 608,230 AIDS cases were reported in Brazil, and between 2000 and 2010 there was a decline in HIV incidence rates in the Southeast from 24.5 to 17.6 cases per 100,000 inhabitants. However, there was an increase in incidence rates for the other regions, with an increase from 27.1 cases/100,000 inhabitants to $28.8 / 100,000$ in the southern region; an increase from 7.0 cases $/ 100,000$ to $20.6 / 100,000$ in the northern region; $13.9 / 100,000$ to $15.7 / 100,000$ in the central-west; and $7.1 / 100,000$ to $12.6 / 100,000$ in the north east ${ }^{(2)}$.

In a study conducted in the five regions of Brazil, $13.2 \%$ of male interviewees reported having had relationships with more than five casual sexual partners in the year preceding the study. Among the women, this percentage was lower (4.1\%). A total of $36.9 \%$ of the men and $17 \%$ of the women reported sexual initiation before 15 years of age. The study also found that $45.7 \%$ 
of the male interviewees reported using condoms in their relationships, while only $16.4 \%$ of the women reported condoms use ${ }^{(3)}$.

A study with 200 participants who were married or in a stable relationship showed that, despite knowing the ways to prevent STD/AIDS, the participants presented risk behavior, justifying this behavior due to their trust in the steady partner. Of the respondents, 95\% knew about condoms as a form of prevention, however, only $14 \%$ reported their use in the last 12 months, and $9 \%$ of the population surveyed had an extramarital relation without using condoms(4). Similar data on the use of condoms in casual relationships have been published by the Ministry of Health, indicating that the number of individuals who had sexual relations with more than five casual partners increased from $4 \%$ in 2004 to $9.3 \%$ in 2008. In these casual relationships the frequency of condom use decreased from $51.6 \%$ in 2004 to $46.5 \%$ in 2008. Another fact to be emphasized is the practice of extramarital relations, with 7.1 million people who live in stable relationships reporting having had extramarital relations, and $63 \%$ of these individuals reporting not having adopted the use of condoms in all their casual relationships(5). The behavior exhibited by heterosexual couples with respect to the practice of safe sex and awareness has been an obstacle to prevent the spread of HIV/AIDS, since there is still a perception that a relationship grounded in love, complicity, respect, loyalty and trust ensures that men and women are protected from the risk of infection ${ }^{(4)}$.

A national study on the knowledge of the population between 15 and 64 years of age regarding HIV infection showed that $96.6 \%$ agreed with the statement that the use of condoms is the best way to avoid HIV infection and $95.7 \%$ agree that a person can be infected during sexual intercourse without a condom ${ }^{(3)}$. However, knowledge itself does not guarantee its apprehension and incorporation into the behavior(6). Given the above, it is necessary to carry out differentiated work in places that are frequented by heterosexual and homosexual couples, with the aim of developing health education programs. The majority of studies involving the theme of prevention of HIV and other STDs have been developed with convenience samples of specific populations, such as homosexuals ${ }^{(7-8)}$, Latin American immigrants living in the USA ${ }^{(9)}$ and Chinese married women(10). No studies were found in the literature that used a sample of people frequenting motels. Considering that this institution attracts a diverse public with respect to sexual orientation, age, gender, marital status, and other features, it is important to investigate the factors related to the use of condoms in sexual intercourse of this diverse and heterogeneous population. The aim of this investigation is to know the risk factors to which the population is exposed, which will, in turn, allow the planning of preventive actions.

Knowing the characteristics related to risk behavior concerning STD infection may contribute to the planning of actions and strategies to be implemented, with educational programs directed toward the environments that are mostly sought for the practice of sexual relations. Considering these aspects, the general aim of this study was to verify risk behavior for HIV infection in people who attended motels of two municipalities of Minas Gerais, Brazil.

\section{Method}

This is a cross-sectional study conducted in two motels in two municipalities (Timóteo and Coronel Fabriciano) in Minas Gerais, Brazil, located in the Vale do Aço region, between March and July 2009. The Metropolitan Region of the Vale do Aço, also known as the Steelmaker Region, is located in the east of the state of Minas Gerais, southeastern Brazil. It has the 11th largest GDP in Brazil. Timóteo has a population of 81,243 people estimated by the 2010 Census and its HDI is 0.831 , which is considered high in relation to the state of Minas Gerais. Coronel Fabriciano had an estimated population of 103,694 inhabitants in 2010, with a HDI 0.789 , considered average in relation to the state of Minas Gerais ${ }^{(11)}$. The study was conducted with the people present in the motels, between March and July 2009. The selection of the times for the development of the study occurred randomly, with data collection occurring on each day of the week, including weekends, in three shifts - morning, afternoon and night - thus avoiding selection bias. It was requested that the participant answered the questionnaire only once in case the person was present at the motel on other days and had already answered the data collection instrument at another time.

The delivery of the questionnaires took place in a way that ensured the confidentiality and privacy of the participants, with the explanation about the research and the invitation to participate in the study made by telephone, at the time that the motel clients were calling the reception requesting the bill. The study questionnaire was left in the room of the client with the bill, which guaranteed the confidentiality of the participation. The estimated time spent completing the questionnaire was calculated to be around 03 minutes and the respondents were informed by telephone that the institution would 
allow five minutes for the clients to leave the site after paying the bill. Thus, there was no inconvenience to the institution and/or the client.

On average, 300 couples attended each participating motel weekly. For the statistical calculation of the sample size an unknown proportion of the use of condoms in the population was considered (estimated proportion of $50 \%$ ) since no similar study was found that investigated the proportion of condom use in motel clients. A significance level of $95 \%$ and a $6 \%$ margin of error were considered, resulting in a minimum sample of 267 individuals to be studied. To compensate for eventual losses, $15 \%$ was added to the calculation, resulting in a final sample size of 307 individuals. The participants of the study were 308 individuals (154 participants in each municipality, $51.6 \%$ female), aged between 18 and 60 years, who were present in the participating motels during the data collection.

A questionnaire containing 16 objective questions was used as the instrument. The questionnaire focused on the last sexual encounter that took place at the motel on the day of data collection and requested that only one person who was in the room responded to the instrument. The questions were related to the use of condoms during vaginal, oral and anal intercourse, the length of the relationship with the other person in the room, if they had a steady partner, and if they drank alcohol or shared drugs during the last intercourse, among other issues. There was the option "did not do" for the questionnaire items.

The data were analyzed with the "Statistical Package for the Social Sciences" (SPSS) version 17.0 program. Initially, descriptive analyzes were performed. Subsequently, bivariate statistical analyzes were performed (chi-square and t test for independent samples) in order to verify the association between the independent variables (age, length of relationship, use of alcohol and drugs, number of partners, if they had a steady partner) and the dependent variable condom use. The level of significance adopted was $p<0.05$. In order to determine which variables were predictors of condom use behavior, multivariate logistic regression analysis was performed.

The study was previously approved by the Research Ethics Committee (REC) of Unileste-MG, under protocol number 2112508. Confidentiality and anonymity were guaranteed, and in no way were the participants identified. It should be noted that the REC dispensed with the use of the Terms of Free Prior Informed Consent (TFPIC) for this study, due to the consideration that by signing the TFPIC the participants would be identified, which would cause embarrassment for them.

\section{Results}

Among the participants, $42.5 \%$ were aged between 18 and 25 years. There were significant differences with respect to the distribution frequency of the genders in each age group $\left(X^{2}=13.59\right.$; $p<0.009$ ), with the frequency of female participants decreasing with increasing age. There was an increase in the frequency of male participants from 35 years of age, as shown in Table 1.

Table 1 - Distribution of the participants by gender and age

\begin{tabular}{lcccc}
\hline Age group & $\begin{array}{c}\text { Female } \\
\mathbf{n}(\%)\end{array}$ & $\begin{array}{c}\text { Male } \\
\mathbf{n}(\%)\end{array}$ & $\begin{array}{c}\text { Total by age } \\
\text { group (\%) }\end{array}$ & $\begin{array}{c}\text { Relative } \\
\text { frequency of } \\
\text { participants by } \\
\text { age group (\%) }\end{array}$ \\
\hline 18 to 25 years & $75(57)$ & $56(43)$ & $131(100)$ & 43.00 \\
26 to 35 years & $62(57.9)$ & $45(42.1)$ & $36(100)$ & 35.10 \\
36 to 45 years & $15(33.3)$ & $30(66.7)$ & $20(100)$ & 14.80 \\
46 to 55 years & $06(37.5)$ & $10(62.5)$ & $13(100)$ & 5.20 \\
Over 56 years & $01(16.7)$ & $05(83.3)$ & $05(100)$ & 2.00 \\
\hline
\end{tabular}

Analyzing the risk behavior for STD infection, it was found that $45.8 \%$ of the participants reported not having used a condom during the last vaginal sexual intercourse, $48.4 \%$ did not use a condom during the last oral sex, while $26.3 \%$ reported not having used a condom during the last anal intercourse.

Table 2 - Frequency of the use of condoms during vaginal, oral and anal intercourse, among those who said they had practiced these sexual relations

\begin{tabular}{lcc}
\hline \multirow{2}{*}{ Sexual intercourse } & \multicolumn{2}{c}{ Condom used? } \\
\cline { 2 - 3 } & Yes (\%) & No (\%) \\
\hline Vaginal & 51.3 & 45.8 \\
Oral & 10.7 & 48.4 \\
Anal & 14.9 & 26.3 \\
\hline
\end{tabular}

The mean age of first sexual intercourse was 16.86 years $(s d=2.91)$. There were no significant differences with regard to mean age at first intercourse, and condom use $(t=1.15 ; d f=1 ; p=0.249)$. Analyzing the data of condom use with the sharing of drugs, it was found that among participants who claimed to have shared drugs during the last sexual relation, $47.8 \%$ reported having used a condom during the last vaginal intercourse. Conversely, $51.6 \%$ of the motel clients who claimed not to have shared drugs reported using a condom during the last vaginal intercourse $\left(X^{2}=9.01\right.$; 
$\mathrm{df}=1 ; \mathrm{p}=0.01)$, revealing significant differences in condom use between drug users and non-users, for this sample. Regarding the use of alcohol, no association was found between alcohol consumption and condom use. Among the participants who reported having used a condom during the last vaginal intercourse, $48.1 \%$ reported having consumed alcohol, while among those who did not use condoms, $51.9 \%$ had not consumed alcohol $\left(X^{2}=0.182 ; d f=1 ; p=0.201\right)$. There were significant differences in condom use between participants who reported having a steady partner and participants who reported not having a steady partner at the time. The frequency of condom use was higher among participants who did not have a steady partner, as shown in Table 3. Comparing the amount of partners over the past six months with the use of condoms, it was observed that among the participants who had intercourse with five or more partners, $63.2 \%$ reported not having used a condom during the last vaginal intercourse. Among those who reported having had intercourse with only one partner in the last six months, $49.7 \%$ reported not having used a condom during the last intercourse. Thus, there was no significant association between the number of partners and the use of condoms $\left(X^{2}=3.21 ; d f=1 ; p=0.07\right)$, as shown in Table 3.

Table 3 - Relationship between condom use, having or not having a steady partner and number of sexual partners in the previous 6 months

\begin{tabular}{llllllll}
\hline \multirow{2}{*}{ Variables } & \multicolumn{2}{l}{$\begin{array}{l}\text { Used condom during } \\
\text { the last intercourse }\end{array}$} & Total & $\mathbf{X}^{2}$ & $\mathbf{d f}$ & $\mathbf{p}$ \\
\cline { 2 - 4 } & \multicolumn{2}{c}{ Yes $\mathbf{n}(\%)$} & No $\mathbf{n}(\%)$ & & & & \\
\hline $\begin{array}{l}\text { Steady Partner } \\
\text { Yes }\end{array}$ & $109(50.9)$ & $113(49.1)$ & $222(100)$ & & & \\
No & $49(63.6)$ & $28(36.4)$ & $77(100)$ & & & 0.02 \\
Number of Partners in the previous 6 months & & & & \\
One & $95(50.3)$ & $94(49.7)$ & $189(100)$ & & & \\
Two to four & $56(61.5)$ & $35(38.5)$ & $91(100)$ & 5.21 & 2 & 0.07 \\
Five or more & $07(36.8)$ & $12(63.2)$ & $19(100)$ & & & \\
\hline
\end{tabular}

It was investigated whether there were differences in condom use between the heterosexuals and homosexuals. With regard to condom use during the last oral sex, there were no significant differences between heterosexuals and homosexuals $\left(X^{2}=2.67\right.$; $d f=1 ; p=0.262)$. Considering the use of condom during the last anal intercourse, $35.3 \%$ of the participants that said they had homosexual intercourse did not use condoms, while $26.2 \%$ of the participants who had heterosexual intercourse reported not having used a condom, with these differences reaching statistical significance $\left(X^{2}=8.28 ; d f=1 ; p=0.01\right)$. There were no significant differences in condom use between the different age groups, considering the last vaginal intercourse $\left(X^{2}=2.53 ; d f=1 ; p=0.638\right)$. A total of $53.5 \%$ of the participants aged between 18 and 25 years reported having used a condom during the last vaginal intercourse, while $83.5 \%$ of the participants aged over 56 years reported having used a condom during the last vaginal intercourse. There was no association between condom use and the length of the relationship, as shown in Table 4. It is noteworthy that $33.3 \%$ of the participants who reported knowing the person they had intercourse with for just one day did not use condoms and $53.3 \%$ of the people who reported being in a relationship with the partner for less than a month also did not use a condom.

Table 4 - Association between the length of the relationship maintained with the person who was with them in the motel and condom use

\begin{tabular}{llllllll}
\hline $\begin{array}{l}\text { Length of } \\
\text { relationship }\end{array}$ & $\begin{array}{l}\text { Used condom in } \\
\text { the last intercourse }\end{array}$ & Total \% & $\mathbf{X}^{2}$ & df & $\mathbf{p}$ \\
\cline { 2 - 5 } & $\begin{array}{l}\text { Yes } \mathbf{n}(\%) \\
\text { No (\%) }\end{array}$ & & & & \\
\hline 1 day & $14(66.7)$ & $07(33.3)$ & $21(100)$ & & & \\
2 days to 1 month & $14(46.7)$ & $16(53.3)$ & $30(100)$ & & & \\
2 months to 1 year & $53(42.4)$ & $39(57.6)$ & $92(100)$ & 4.57 & 4 & 0.333 \\
13 months to 3 year & $39(53.4)$ & $34(46.6)$ & $73(100)$ & & & \\
Over 4 years & $38(45.8)$ & $45(54.2)$ & $83(100)$ & & & \\
\hline
\end{tabular}

In order to determine which factors would best explain the use of condoms, a multivariate logistic regression model was constructed using the independent variables: age, number of partners in the last six months, steady partner, drug use, alcohol use, difficulty in proposing condom use and length of relationship, and the dependent variable condom use during last vaginal sexual intercourse. Table 5 presents the results of the logistic regression analysis.

Table 5 - Multivariate logistic regression analysis to investigate the predictors of condom use

\begin{tabular}{lcccc}
\hline Variables & $\begin{array}{c}\text { Odds } \\
\text { Ratio }\end{array}$ & \multicolumn{2}{c}{$\begin{array}{c}\text { IC95\% } \\
\text { (Lower-Upper) }\end{array}$} & p-value \\
\hline Difficulty in proposing & 0.831 & 0.630 & 1.096 & 0.189 \\
Length of relationship & 0.947 & 0.739 & 1.216 & 0.671 \\
Age & 1.048 & 0.821 & 1.339 & 0.705 \\
Number of partners & 0.683 & 0.400 & 1.156 & 0.156 \\
Age of sexual initiation & 0.964 & 0.886 & 1.050 & 0.401 \\
Drug use & 0.807 & 0.308 & 2.114 & 0.663 \\
Alcohol use & 1.32 & 0.808 & 2.156 & 0.268 \\
Fixed Partner & 0.45 & 0.204 & 0.989 & 0.040 \\
\hline
\end{tabular}


The results of multivariate logistic regression indicated that, in the constructed model, the variable that significantly predicted the use of condoms during vaginal intercourse was to have a steady partner. An alternative interpretation of the odds ratio is the transformation of this value in terms of percentage effects, using the formula $=$ Percentage effect on the probability of occurrence of the event $=(O R-1) \times 100^{(10)}$. Therefore, the analysis of the results of the steady partner variable $=(0.45-1) \times 100=$ - 55\%, indicating that the fact that the participant has a steady partner reduced by $55 \%$ the likelihood of using a condoms, compared with those without a steady partner, considering that the other independent variables of the model are constant.

\section{Discussion}

The data revealed that no association was found between age at the initiation of intercourse, and condom use, indicating that the mean age of initiation of sexual activity did not differ between participants who used and those who did not use condoms. With respect to the sharing of drugs, it was observed that the frequency of condom use was significantly lower among participants who reported having shared drugs during the last intercourse. Contrary to literature data which indicate that alcohol consumption increases vulnerability to sexual intercourse without condoms ${ }^{(3,12)}$, in the present study no association was found between alcohol use and condom use. No association was encountered between condom use and the length of the relationship. However, one aspect to be highlighted is the high frequency of non-condom use in casual relationships with partners known for less than a month, behavior that increases vulnerability to infection by HIV and other STDs.

The logistic regression analysis revealed that, considering all the risk factors together, the factor that most contributed to the failure to use condoms was having a steady partner. This data is in agreement with the literature showing that confidence in a stable partner contributes to not using condoms ${ }^{(3,6,9)}$. A study performed with Mexican immigrants residing in the United States revealed the belief that a request for condom use by married women indicates mistrust and a lack of love for the partner. Thus, these women believe that having sex without a condom is proof of trust in the marriage, behavior that exposes them to a greater risk of HIV infection $^{(9)}$.

A study developed with HIV seropositive mothers revealed that trust and loyalty are the main reasons why the person does not require the use of condoms, and therefore, facilitators of the denial of the risk. Therefore, a prolonged relationship contributes to the woman presenting the feeling that she is immune to HIV and the trust in the partner contributes to the wives disregard of the previous life of her husband(6).

There are also cultural issues that must be considered. In societies where there are inequities in terms of gender, where the woman has a submissive role in relation to the man, condom use is even less frequent ${ }^{(13)}$. The low selfesteem of women and the lack of autonomy and economic dependence limit the ability of women to communicate with their partner and negotiate condom use. In marriage, gender roles and social stereotypes are present in all aspects of the quotidian life. The cultural aspects that encourage men to have more than one sexual partner should also be highlighted, as this behavior is not tolerated in women ${ }^{(14)}$. Considering that in the present study the fact of having a steady partner was the main factor explaining the failure to use condoms, this situation increases the risk of the woman contracting STD/HIV.

Further analysis of the results of this study revealed that there were married participants who were in the motel with a partner who they had known for just one day, and that a condom was not used during the last sexual intercourse. These data will be explored in a future work and they strengthen the hypothesis of vulnerability of married women to HIV infection. One study investigated the factors related to sexual intercourse without condoms among male participants ${ }^{(7)}$. The results indicated that the main factors associated with not using condoms were related to issues of sexual satisfaction, adventure and intimacy. Thus, the researchers argued that the campaigns regarding HIV prevention only slightly address the libidinal aspects, which are psychological elements central to the adherence to the use of condoms, and should be included in the campaigns for condom use.

\section{Conclusion}

The results of this study revealed that approximately half of the participants did not use a condom during the last vaginal intercourse or oral sex. The main determinant variable for not using condoms was the fact of having a steady partner. This data provides support to think about the need for effective campaigns involving issues that permeate the belief of the population, such as the stereotype of security and trust in stable relationships.

\section{References}

1. Barbosa R, Koyama MAH. Comportamento e práticas sexuais de homens e mulheres. Rev Saúde Pública.2008;42(1):21-33. 
2. Ministério da Saúde. Aids no Brasil [Internet]. Brasília: Ministério da Saúde; 2012 [acesso 06 mar 2012]. Disponível em: http://www.aids.gov.br/pagina/ aids-no-brasil.

3. Ministério da Saúde (BR). Pesquisa de Conhecimentos, Atitudes e Práticas da População Brasileira de 15 a 64 anos de idade. [Internet]. Brasília (Brasil): Programa Nacional de DST e Aids; 2009.[acesso 18 jun 2008]. Disponível em: http://www.aids.gov.br/sites/default/files/anexos/ publicacao/2009/40352/pcap_2008_f_pdf_13227.pdf

4.Maia C, Guilhem D, Freitas D. Vulnerabilidade ao HIV/ aids de pessoas heterossexuais casadas ou em união estável.Rev Saúde Pública.2008;42(2):242-8.

5. Ministério da Saúde (BR). Comportamento sexual e uso do preservativo na população brasileira. [Internet]. Brasília: PCAP; 2008. [acesso 20 ago 2009]. Disponível em: http://www.aids.gov.br/portalaids_services/data/ documents/storedDocuments/\%7BB8EF5DAF-23AE4891-AD36-1903553A3174\%7D/\%7BFB7ECC9A-CDF1440E-AF64-53CE1C5BAE6B\%7D/PCAP-BR\%20CNAIDS. ppt\#451,9, Comportamento sexual e uso do preservativo na população brasileira.

6. Neves LAS, Gir E. Crenças das mães soropositivas ao HIV acerca da transmissão vertical da doença. Rev. LatinoAm. Enfermagem.set-out 2006;14(5):140-7.

7. Carballo-Diéguez A, Ventuneac A, Dowsett GW, Balan I, Bauermeister J, Remien $\mathrm{RH}$, et al. Sexual Pleasure and Intimacy Among Men Who Engage in "Bareback Sex". AIDS and Beh. 2011;15, Suppl 1:S57-65.

8. Mora C, Monteiro S. Vulnerability to STIs/HIV: sociability and the life trajectories of young women who have sex with women in Rio de Janeiro. Culture Health Sexual.2010;12(1):115-24.

9. Hirsch JS, Higgins JBA, Bentley ME, Nathanson CA The Social Constructions of Sexuality: Marital Infidelity and Sexually Transmitted Disease-HIV Risk in a Mexican Migrant Community. Am J Public Health. 2002; 92(8):122737.

10. Hong $H$, Qin $Q R$, Li LH, Ji GP, Ye DQ. Condom use among married women at risk for sexually transmitted infections and HIV in rural China. Int J GynecolObstetrics. 2009;106:262-5.

11. Instituto Brasileiro de Geografia e Estatística [Internet]. Censo Demográfico 2010. [acesso 15 jun 2011]. Disponível em http://www.ibge.gov.br/cidadesat/ topwindow.htm?1.

12. Cardoso LRD, Malbergi A, Figueredo TFB. O consumo de álcool como fator de risco para a transmissão das DSTs/ HIV/Aids.Rev PsiqClín. 2008:5(supl 1):70-5.

13. Jacubowski N. Marriage is not a safe place: Heterosexual marriage and HIV-related vulnerability in Indonesia.Culture, Health Sexual.2008;10(1):87-97.
14. Wang BO, Li X, Stanton B, Fang X, Liang G, Liu H, et al. Gender Differences in HIV-Related Perceptions, Sexual Risk Behaviors, and History of Sexually Transmitted Diseases Among Chinese Migrants Visiting Public Sexually Transmitted Disease Clinics. AIDS Patient Care and STDs. 2007;21(1):57-68. 